\title{
Deprivation viewed from a multidimensional perspective: The case of Brazil
}

\author{
Ana Flavia Machado, Andre Braz Golgher \\ and Mariangela Furlan Antigo
}

ABSTRACT

This study uses the capability approach to undertake a multidimensional analysis of deprivation in urban areas of Brazil between 2003 and 2008 based on a four-dimensional index (living conditions, health, level of education and participation in the labour market) constructed out of 13 different indicators. Its findings indicate that a majority of the population is living in households that are not experiencing deprivation and that, of those that are, the instance of deprivation is confined to a single indicator. When the results were then compared with the income-poverty index for the different states in Brazil, the outcome confirmed that regional inequalities show up in both types of measurements. Finally, synthetic cohort data and ordinary least squares (OLS) models were used to study the relationship between personal attributes and a propensity to lapse into poverty and/or to remain poor. University of Minas Gerais (UFMG). afmachad@cedeplar.ufmg.br

Andre Braz Golgher, Associate Professor, Centre for Regional Development and Planning (cedeplar) of the Federal University of Minas Gerais (UFMG). agolgher@cedeplar.ufmg.br

Mariangela Furlan Antigo, Associate Professor, Centre for Regional Development and Planning (cedePlar) of the Federal University of Minas Gerais (UfMG).mantigo@cedeplar.ufmg.br 


\section{I}

\section{Introduction}

The introduction of the capability approach placed a range of new welfare-related concepts on the research agenda (Sen, 1999). These concepts, which include functionings, capabilities and agency, have broadened the field of poverty studies and have allowed researchers to overcome the limitations of traditional indicators, which are based primarily on such concepts as assets, consumption, income and utility.

A number of recent studies have undertaken multidimensional analyses of the data for Brazil based on the capability approach. For example, D'Ambrosio and Rodrigues (2008) used a non-monetary system of measurement that draws on various indicators of individual well-being, while Neri (2008) constructed a human development index out of variables relating to health, diet, income, the prevailing economic and political situation, the labour market and other factors. Bagolin and Ávila (2006) and Lopes, Macedo and Machado (2003 and 2004) measured deprivation from a multidimensional standpoint based on fuzzy clustering theory. Silva and Barros (2006) and Rocha, Moreira and Santos (2008) have also built a multidimensional index to measure deprivation in households, regions and specific sectors of the population. Golgher (2010a) analysed Brazilian households' perceived deprivation and found that deprivation profiles differed markedly between urban and rural areas. He also found very little correlation between deprivation and income for most of the dimensions covered in his study (Golgher, 2010b).

While this study will also look at poverty in Brazil from a multidimensional perspective using the capability approach, its objectives and the methodology it uses are different. It is based on a multidimensional deprivation index (MDI) inspired by the methodology proposed by Alkire and Foster (2007) and applied in 104 developing countries, including Brazil, by Alkire and Santos (2010). The MDI has four dimensions (housing conditions, health, education and the labour market) that are captured by 13 non-monetary indicators (see table 2). The measurements using this index indicate that a majority of the population lives in households that are not experiencing deprivation and that, of those that are, the instance of deprivation is confined to a single indicator. Households shown to be lacking in respect of numerous indicators represent only a small proportion of the total.
Income poverty levels will be compared with the MDI measurements taken in 2003 and 2008. Regional data mapping points to a considerable degree of spatial heterogeneity across the states of Brazil. The existence of markedly different geographic profiles shows that, as noted by Baulch and Masset (2003), monetary and non-monetary poverty indicators in developing countries do not tell the same story. These initial results provide a broader picture of poverty in Brazil from both a monetary and a multidimensional perspective.

The common features and relationships among the 13 MDI indicators were taken into account. The indicator for sanitation services or sewerage systems was the most significant one for Brazil from both a one-dimensional and multidimensional standpoint. Some aspects of deprivation can show up in two or more indicators, as in the case of water and sewerage systems, child labour and school non-attendance, and the presence of working adults, unemployed adults and functional illiterates in the home. These results are confirmed by a factor analysis.

This article is divided into seven sections, including this introduction, which seeks to provide the context for this analysis. The second section describes the methodology that was used to construct the multidimensional deprivation index (MDI), the database that was employed and the different dimensions of deprivation that were studied. The results obtained using the MDI are discussed in the four following sections, each of which has a specific focus. The third section provides an overview of the index and of how it compares with monetary poverty measurements, while the others deal with different facets of the MDI. The fourth section discusses the results for the different states in Brazil, which reveal regional differences with very little correlation to one another. The fifth section analyses some of the specific aspects of each dimension of deprivation as well as common features and relationships. The sixth section looks at patterns of deprivation using synthetic cohort data and an ordinary least squares (OLs) model in order to provide an overarching picture of deprivation in urban areas of Brazil from a dynamic, multidimensional vantage point. The final section presents a number of considerations and conclusions. 


\section{II \\ The multidimensional deprivation index (MDI), data and indicators}

The capability approach posits that individual differences determine the degree to which each person will be able to transform the resources at his or her command into capabilities and that those capabilities cannot be measured on the basis of available resources but rather on the basis of what people can become and can do with them. As proposed by Sen (2001), the incompleteness of the capability approach is what allows its basic objective to be preserved, since that incompleteness gives researchers the freedom to choose and describe the functionings and capabilities that they feel are relevant.

Starting from this premise, data were drawn from the Brazilian national household survey results for 2003 and 2008 and their special supplements. These datasets are very complete, but they were not created for the purpose of describing people's perceptions of deprivation. We therefore decided to use a methodology similar to the one proposed by Alkire and Foster (2007). A brief discussion of the methodology and the deprivation index used in this analysis follows, along with an outline of the database and the dimensions and indicators used to construct it.

\section{Review of the multidimensional deprivation index (MDI)}

The deprivation index for Brazil was constructed using the methodology proposed by Alkire and Foster (2007), which was applied to a number of developing countries by Alkire and Santos (2010). The first step was to define the main dimensions of the functionings and capabilities to be studied: housing conditions, health, education and participation in the labour market. ${ }^{1}$ These dimensions were then divided into 13 indicators, as shown in table 1.

Housing conditions include access to sanitation services and running water, the disposal of household

1 Alkire and Santos (2010) defined these dimensions in terms of the Millennium Development Goals and used a secondary database such as the one used in this study.

TABLE 1

MDI dimensions, indicators and their weightings

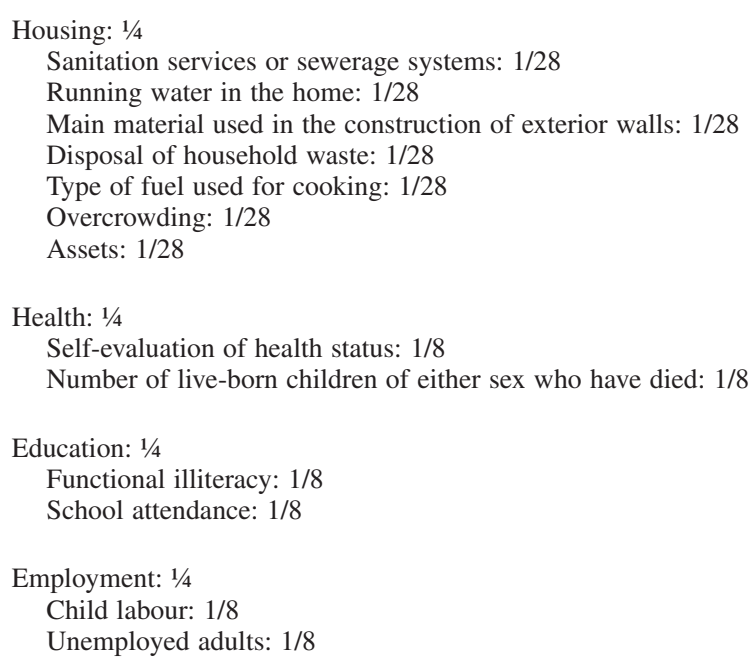

Source: prepared by the authors.

MDI: multidimensional deprivation index. 
waste, the type of fuel used for cooking, the presence of household goods (assets), the material that the walls in the dwelling are made of and an overcrowding indicator. The health indicators used were a self-evaluation of health status and deaths of live-born children. Functional illiteracy and school attendance were the education indicators. Two indicators were used to measure the employment dimension: child labour and unemployed adults in the household. These indicators will be described in greater detail in the following section.

Once the MDI dimensions and indicators had been defined, the next step was to establish the relative importance of each one. Decancq and Lugo (2010) compared eight different approaches to the weighting of multidimensional indices. These approaches can be categorized as being based on data-driven, normative or hybrid weightings. Following along these lines, Alkire and Foster (2007) argue that each dimension should be weighted on the basis of normative criteria (human rights, international conventions, national legislation, political consensus, etc.) and that, within each dimension, the ranking can be based on a data-driven normative approach. Within that normative framework, equal or arbitrary weightings can be assigned (Decancq and Lugo, 2010).

Alkire and Santos (2010) opted for equal weightings of the various dimensions and, within each dimension, used a database that had been created for applications other than the application of the capability approach in a strict sense. Following these authors, we chose to use equal weightings for each dimension (1/4) and equal weightings for the indicators included in each dimension (see table 1).

Estimates for each indicator were prepared at the household level. When the value of an indicator drops below a set threshold, the people living in that household are classified as poor; otherwise, they are classified as non-poor. Thus, households are classified either as non-poor or as being subject to deprivation in terms of at least one of the 13 indicators used in the study.

Alkire and Foster (2007) have sought to calibrate the percentage of poor persons classified as being deprived in terms of each indicator $(\mathrm{H})$ by measuring the extent of deprivation. They defined the standardized distance (A) as the distance between the observed value and an arbitrary limit defined for each indicator. If the observed value is equal to or higher than the deprivation threshold, the standardized differential takes a value of zero (0). This type of standardization provides a means of ordering the indicators and comparing them.
Thus, the MDI as defined by Alkire and Santos (2010) is given by:

$$
\mathrm{MDI}=\mathrm{H} * \mathrm{~A}
$$

\section{Data sources and indicators}

The data were drawn from the 2003 and 2008 national household surveys and their special supplements, which include information on living conditions and health. Data on individuals and households were used, and the indicators were estimated at the household level.

The data are for urban areas only, since the indicators for some of the dimensions differ sharply depending on whether they refer to urban or rural areas, which would make it difficult to use a single definition of deprivation for both. For example, a rural dwelling that does not have running water may not be classified as poor, whereas this would not be the case of a dwelling in an urban area. For the purposes of collecting data on household deprivation, pensioners, domestic workers and family members of domestic workers were excluded. The unexpanded sample was composed of 289,766 people in 2003 and 312,872 people in 2008.

As can be seen from table 1, the MDI has four dimensions: housing conditions, health, education and employment. The first three bear a direct relationship to the index proposed by Alkire and Santos (2010) that has been adapted for the data used in this study, while the fourth dimension was included to take account of specific features of the situation in Brazil.

As detailed in table 2, the first dimension (housing conditions) is covered by seven indicators. A value of (0) is assigned to people living in households that are not experiencing deprivation in respect of this indicator, and a value of (1) is assigned to those who do. Access to public utilities for sewerage systems, running water and the disposal of household waste helps to increase a dwelling's value, but the greatest impact of the presence of these utilities is felt in a reduction in morbidity and mortality. Housing conditions are also measured in terms of the presence of a gas or electric stove, access to private goods (mobile telephone, radio, colour television, a one- or two-door refrigerator) and wall coverings/surfaces. These variables were used to measure the extent of residents' ability to meet their basic needs, including the need for information, and the extent to which their dwellings are protected from the elements. The number of people who sleep in rooms that are designated as bedrooms (the overcrowding indicator) is another important variable for 


\section{Description of MDI indicators, by dimension}

A. Housing conditions

A.1 Sanitation services or sewerage systems

(1) Septic tank not connected to the sewerage or storm drain systems, rudimentary pit, ditch, direct disposal into a river, lake, sea or other body of water

(0) Sewerage or storm drain system, septic tank connected to the sewerage or storm drain system

A.2 Running water

(1) Well, spring or other

(0) General distribution network

A.3 Disposal of household waste

(1) Indirect collection, burning, burying on property, disposal in empty lots or public areas, dumping into rivers, lakes, seas or other areas

(0) Direct collection

A.4 Type of fuel used for cooking

(1) Firewood, coal, electricity or other fuel

(0) Bottled gas or piped-in natural gas

A.5 Assets

(1) None or only one of the following assets in the household: mobile telephone, radio, colour television set, one- or two-door refrigerator

(0) At least two such assets

A.6 Main material used in external housing walls/surfaces

(1) Adobe, scrap wood, straw or other

(0) Bricks or lumber

A.7 Overcrowding

(1) Three or more people per bedroom

(0) One or two persons per bedroom

B. Health

B.1 Self-evaluation of health status

(1) At least one household member says that $\mathrm{s} / \mathrm{he}$ is in poor or very poor health

(0) All household members say that their health status is very good, good or fair

B.2 Number of live-born children of either sex who have died

(1) 1 or more

(0) None

\section{Education}

C.1 Functional illiteracy

(1) 1 or more persons aged 14 or over have no more than 3 years of schooling

(0) No one in the household aged 14 or over has only 3 years of schooling or less

C.2 School attendance

(1) 1 or more members of the household between the ages of 6 and 18 do not attend school

(0) No one in the household between the ages of 6 and 18 does not attend school

D. Labour market

D.1 Child labour

(1) 1 or more members of the household between the ages of 5 and 17 is working

(0) No one in that age group is working

D.2 Unemployed adults

(1) 1 or more members of the household are classified as: aged 18 years or older and unemployed; unemployed, not attending school and not receiving income of any sort; or under 18 years of age and employed

(0) No one in any of the above categories

Source: prepared by the authors.

MDI: multidimensional deprivation index.

measuring people's capabilities in terms of their health and self-esteem.

Health was included as a variable because a person's physical and psychological status is a fundamental determinant of their ability to develop capabilities and have freedom to choose different functionings. Two indicators are used for this purpose: a self-evaluation of health status, and the number of deaths of live-born children of either sex. The first indicator synthesizes individuals' perception of their own health. Answers of "very good", "good" and "fair" were grouped together into a single category (healthy), while the responses "very poor" and "poor" were grouped into another (unhealthy). According to Noronha (2005), the literature does not reflect any consensus as to the best approach to use in order to classify self-evaluations of health status, 
so this fairly limited definition has been used in this case. The indicator of deaths of live-born children is an indirect measurement of premature death and general health standards.

The presence of functional illiterates in the household and children's and adolescent's rate of school attendance are the indicators used to gauge the educational dimension of the index. In addition to being important in and of itself, education is a vehicle for training as defined in the capability approach in that it facilitates the exercise of agency in a series of functionings, such as being in good health, having a decent job, exercising citizenship, appreciating works of art and cultural events, etc.
The fourth and last dimension is captured by the indicators for child labour and the presence of unemployed adults in the household. Participation in the labour market by persons in the age brackets in which such participation is compatible with the overall course of human development is a decisive factor in averting deprivation and having the ability to engage in many important functionings.

The following four sections will discuss the MDI results. Each focuses on a specific facet of what will, taken together, provide a fuller, multidimensional picture of the situation of deprivation in urban areas of Brazil. The following section will provide an overview of the index.

\section{III}

\section{Overall results of the multidimensional deprivation index (MDI)}

This section will cover the overall results of the MDI for urban areas of Brazil between 2003 and 2008 in order to provide an overview of recent changes in patterns of deprivation. As noted earlier, households may be classified as not experiencing deprivation of any sort or as exhibiting deprivation in terms of at least one of 13 different indicators. The number of people experiencing deprivation as measured by each of the indicators is shown in table 3 .

The first point to be noted is that, although the urban population in Brazil rose from 132 million to 152 million during the period under study, the actual number of people living in poverty, as measured by the multidimensional index, only climbed from 91 million

TABLE 3

Distribution of people experiencing deprivation, by number of indicators

\begin{tabular}{|c|c|c|c|c|c|c|}
\hline \multirow{2}{*}{$\begin{array}{l}\text { Number of indicators } \\
\text { registering deprivation }\end{array}$} & \multicolumn{2}{|c|}{$\begin{array}{l}\text { Number of persons } \\
\text { (thousands) }\end{array}$} & \multicolumn{2}{|c|}{ Percentage } & \multicolumn{2}{|c|}{$\begin{array}{l}\text { Percentage of persons } \\
\text { experiencing deprivation }\end{array}$} \\
\hline & 2003 & 2008 & 2003 & 2008 & 2003 & 2008 \\
\hline 0 & 41104 & 57489 & 31.1 & 38.0 & - & - \\
\hline 1 & 46363 & 51021 & 35.0 & 33.6 & 50.9 & 54.2 \\
\hline 2 & 27330 & 27232 & 20.7 & 18.0 & 30.0 & 28.9 \\
\hline 3 & 11866 & 10992 & 9.0 & 7.2 & 13.0 & 11.7 \\
\hline 4 & 4085 & 3671 & 3.1 & 2.4 & 4.5 & 3.9 \\
\hline 5 & 1173 & 1028 & 0.9 & 0.7 & 1.3 & 1.1 \\
\hline 6 & 244 & 197 & 0.2 & 0.1 & 0.3 & 0.2 \\
\hline 7 & 23 & 21 & 0.0 & 0.0 & 0.0 & 0.0 \\
\hline 8 & 11 & 6 & 0.0 & 0.0 & 0.0 & 0.0 \\
\hline 9 & 0 & 0 & 0.0 & 0.0 & 0.0 & 0.0 \\
\hline 10 or more & 0 & 0 & 0.0 & 0.0 & 0.0 & 0.0 \\
\hline Total deprivation & 91096 & 94168 & 68.9 & 62.1 & 100.0 & 100.0 \\
\hline Total population & 132200 & 151657 & 100.0 & 100.0 & - & - \\
\hline
\end{tabular}

Source: prepared by the authors on the basis of Brazilian Geographical and Statistical Institute (IBGE), 2003 and 2008 national household surveys. 
to 94 million. This translates into a reduction, in relative terms, from $68.9 \%$ to $62.1 \%$ of the urban population. This means that, in the space of just five years, the percentage of the population that is not living in poverty jumped from $31.8 \%$ to $37.9 \%$, thanks to the country's recent progress in socioeconomic terms.

As shown in the last two columns of table 3, in the households whose members were experiencing some degree of deprivation in $2003,50.9 \%$ of them were deprived of the asset or service represented by a single indicator, while in 2008 the corresponding figure was 54.2\%. The percentage of households experiencing deprivation as measured by six or more indicators was so small as to be statistically insignificant, and the results for deprivation as measured by 10 or more indicators were nil.

There was a relative increase in the proportion of people residing in households which were experiencing deprivation as measured by a single indicator and a decrease in all the other categories. This means that multidimensional poverty declined in Brazil between 2003 and 2008. This shift is attributable to two different trends: the relative number of people in deprived households dropped; and the proportion of deprived households that were experiencing deprivation in respect of a single indicator rose.
Table 4 shows the MDI results as described in the section on methodology (section II), with members of households that are experiencing deprivation as measured by at least one of the 13 indicators being classified as poor. The proportion of the urban population of Brazil experiencing deprivation $(\mathrm{H})$ as measured by at least one indicator amounted to $68.9 \%$ in 2003 and $61.7 \%$ in 2008. If the cut-off is deprivation as measured by at least two indicators, the figures drop to $33.8 \%$ and $28.0 \%$, respectively.

The mean intensity of deprivation (A), calculated as the weighted average of multidimensional deprivation among the poor population for each category of deprivation indicators, is shown in the third and fourth columns. The reader will see that the value increases every time another indicator is added. This is because poor (deprived) people who are experiencing multidimensional deprivation are the ones who experience this condition most intensely. The last two columns show the MDI (the product of $\mathrm{H}$ and $\mathrm{A}$ ) for 2003 and 2008. This measurement indicates that $0.718 \%$ and $0.584 \%$ of the people residing in households experiencing deprivation as measured by at least one indicator are subject to multidimensional poverty.

TABLE 4

Brazil: multidimensional deprivation index (MDI), 2003 and 2008

\begin{tabular}{|c|c|c|c|c|c|c|}
\hline \multirow{2}{*}{$\begin{array}{l}\text { Number of indicators registering } \\
\text { deprivation (as a minimum) }\end{array}$} & \multicolumn{2}{|c|}{$\begin{array}{c}\mathrm{H} \\
\text { (percentages) }\end{array}$} & \multicolumn{2}{|c|}{ A } & \multicolumn{2}{|c|}{ MDI } \\
\hline & 2003 & 2008 & 2003 & 2008 & 2003 & 2008 \\
\hline 1 & 68.9 & 61.7 & 0.010419 & 0.009453 & 0.718 & 0.584 \\
\hline 2 & 33.8 & 28.0 & 0.014732 & 0.014405 & 0.499 & 0.404 \\
\hline 3 & 13.2 & 10.2 & 0.019342 & 0.019978 & 0.255 & 0.203 \\
\hline 4 & 4.2 & 3.1 & 0.024177 & 0.025584 & 0.101 & 0.079 \\
\hline 5 & 1.1 & 0.8 & 0.029085 & 0.030654 & 0.032 & 0.023 \\
\hline 6 & 0.2 & 0.1 & 0.034284 & 0.036870 & 0.007 & 0.005 \\
\hline 7 & 0.0 & 0.0 & 0.039192 & 0.045191 & 0.001 & 0.001 \\
\hline 8 & 0.0 & 0.0 & 0.043282 & 0.050437 & 0.000 & 0.000 \\
\hline 9 & 0.0 & 0.0 & 0.052198 & & 0.000 & \\
\hline 10 or more & 0.0 & 0.0 & & & & \\
\hline
\end{tabular}

Source: prepared by the authors on the basis of Brazilian Geographical and Statistical Institute (IBGE), 2003 and 2008 national household surveys. 


\section{IV}

\section{Analysis of the multidimensional index, by indicator}

This section will take a more detailed look at the deprivation indicators used to construct the MDI. Since the results for 2003 and 2008 are so similar, only those for 2008 will be reported here.

Table 5 shows the distribution of relative deprivation for each of the 13 indicators, including both persons who experience deprivation as measured by a single indicator (one-dimensional poverty) and those who experience it as measured by more than one indicator (multidimensional poverty). The upper panel of table 5 shows the totals for each indicator (i.e., the number of people for which a value of 1 was recorded for the specified indicator, either as a one-dimensional or as a multidimensional measurement).

TABLE 5

Distribution of the population, by type of deprivation

\begin{tabular}{lc}
\hline Type of deprivation & $\begin{array}{c}\text { Number of persons } \\
\text { experiencing deprivation } \\
\text { (thousands) }\end{array}$ \\
\hline Tetal population, by type of deprivation & $\begin{array}{c}\text { Proportion of urban } \\
\text { population in Brazil } \\
\text { (percentages) }\end{array}$ \\
Deaths of live-born children & 47884 \\
Disposal of household waste & 24814 \\
School attendance & 14683 \\
Child labour & 12605 \\
Overcrowding & 11484 \\
Assets & 10200 \\
Water & 8389 \\
Functional illiteracy & 8246 \\
Self-evaluation of health status & 7742 \\
Unemployed adults & 5373 \\
Fuel used for cooking & 5256 \\
Material used to build house walls & 2096 \\
\hline
\end{tabular}

Material used to build house walls

Most common combinations of indicators

\begin{tabular}{lrr}
\hline Sewerage system & 19249 & 12.1 \\
Deaths of live-born children & 9008 & 5.6 \\
Disposal of household waste & 5066 & 3.2 \\
Sewerage system / Deaths of live-born children & 4286 & 2.8 \\
School attendance & 3592 & 2.3 \\
Overcrowding & 3295 & 2.1 \\
Child labour & 3192 & 2.0 \\
Assets & 2651 & 1.7 \\
Sewerage system /Water & 2589 & 1.7 \\
Sewerage system / Disposal of household waste & 2317 & 1.5 \\
Sewerage system / School attendance & 1733 & 1.1 \\
Sewerage system / Child labour & 1662 & 1.1 \\
Sewerage system / Overcrowding & 1578 & 1.0 \\
\hline
\end{tabular}

Sewerage system / Overcrowding

Other single indicators

\begin{tabular}{lrr}
\hline Self-evaluation of health status & 1478 & 0.9 \\
Water & 1171 & 0.7 \\
Functional illiteracy & 1107 & 0.7 \\
Unemployed adults & 883 & 0.6 \\
Fuel used for cooking & 235 & 0.1 \\
Material used to build house walls & 94 & 0.1 \\
\hline
\end{tabular}

Source: prepared by the authors on the basis of Brazilian Geographical and Statistical Institute (IBGE), 2008 national household survey. 
The most numerically significant indicator of deprivation was the indicator for sanitation services or sewerage systems, with more than 47 million Brazilians (31.6\% of the urban population) registering the absence of this amenity. The second-most significant indicator was "deaths of live-born children", with over 24 million Brazilians living in households where such a death had taken place. The third-most significant indicator in terms of the number of instances of deprivation was that of "disposal of household waste" (14 million people), followed by "school attendance", "child labour" and "overcrowding" (over 10 million people each). The totals for the other indicators varied from slightly more than 8 million people (household assets) to less than 1 million people (material used to construct the walls of the house).

The figures refer to the total for each indicator of deprivation. The rest of table 5 gives a more detailed picture. For example, many of the more than 47 million people who do not have a sewerage connection in their home do not experience deprivation as measured by any of the other indicators, whereas some also register other indicators of deprivation. In other words, some households register only one indicator of deprivation while others register two or more (Ferreira and Lugo, 2012). Table 5 shows the most numerically significant combinations of indicators, which were registered by over $1 \%$ of Brazilian households. The potential number of combinations is enormous, since people registering a single indicator of deprivation can have any one of 13 profiles (the total number of indicators), while those registering two indicators could have one of 72 profiles (the number of possible combinations of any two of the 13 indicators) those registering three indicators could exhibit any one of 286 profiles, and so on.

The most commonly registered indicator was "sewerage system", with over 19 million Brazilians experiencing deprivation only with respect to this indicator. The next-most common (also one-dimensional) profiles were those corresponding to "deaths of live-born children" and "disposal of household waste", with over 5 million people registering those types of deprivation in each case. The fourth-most common profile was a combination of two indicators: "sewerage system" and "deaths of live-born children", with over 4 million people exhibiting that profile. This is followed by four different one-dimensional profiles: "school attendance", "overcrowding", "child labour" and "household assets", with over $1.5 \%$ of the urban population in Brazil exhibiting each of these profiles. They are followed by another five two-dimensional instances of deprivation that do not include the lack of a sewerage system. None of the two-dimensional profiles that does not include the lack of a sewerage system were very common, and the same is true of all of the profiles corresponding to three or more indicators of deprivation.

As shown in the lower portion of table 5, the other six one-dimensional profiles are less significant in numerical terms, with the percentage of the urban population of Brazil displaying these profiles ranging between $0.1 \%$ and $0.9 \%$.

As discussed by Ferreira and Lugo (2012), it is best, whenever possible, to analyse multidimensional poverty from the standpoint of the distribution of the different combinations of indicators. Table 6 shows the five most common profiles for each of the 13 indicators. For example, in the case of people who lack sanitation services or a sewerage system in the home, the most common profile was one-dimensional for that indicator. The next-most common one was the two-dimensional profile denoted by the indicators "sewerage system" and "deaths of live-born children", followed by three other two-dimensional profiles: "sewerage system" in combination with "water", with "disposal of household waste" and with "school attendance". These results suggest that improving people's housing conditions by providing hook-ups to a sewerage system may have direct and indirect implications in terms of the levels of deprivation existing in the urban areas of Brazil. In other words, increased access to a sewerage system would have a direct effect in reducing the level of deprivation associated with this indicator, and may also have an indirect effect that would be reflected in a reduction in the levels of deprivation associated with the indicators of deaths of live-born children, water, the collection of household waste and/or school attendance, among others.

Similar analyses can be undertaken for the other indicators. For example, households registering the indicator "deaths of live-born children" were, in most cases, households with one-dimensional profiles. The next-most common were four two-dimensional profiles in which that indicator was combined with the indicators for "sewerage system", "disposal of household waste", "school attendance" and "overcrowding", in that order.

In a majority of cases, the most common profile corresponded to the single indicator in question. The indicators for the type of water supply, the fuel used for cooking and the material used to build house walls are exceptions in that the most common profiles for these indicators are two-dimensional profiles that are combined with the "sewerage system" indicator. There are also some fairly common three-dimensional profiles, such 
Distribution of types of deprivation as measured by at least one indicator

\begin{tabular}{|c|c|c|c|c|c|}
\hline \multirow{2}{*}{ Indicator } & \multicolumn{5}{|c|}{ Most numerous (in combination with) } \\
\hline & First & Second & Third & Fourth & Fifth \\
\hline Sewerage system & - & $\begin{array}{l}\text { Deaths of } \\
\text { live-born } \\
\text { children }\end{array}$ & Water & $\begin{array}{c}\text { Disposal of } \\
\text { household waste }\end{array}$ & School attendance \\
\hline Deaths of live-born children & - & $\begin{array}{l}\text { Sewerage } \\
\text { system }\end{array}$ & $\begin{array}{l}\text { Disposal of } \\
\text { household } \\
\text { waste }\end{array}$ & School attendance & Overcrowding \\
\hline Disposal of household waste & - & $\begin{array}{l}\text { Sewerage } \\
\text { system }\end{array}$ & $\begin{array}{l}\text { Deaths of } \\
\text { live-born } \\
\text { children }\end{array}$ & $\begin{array}{l}\text { Deaths of live- } \\
\text { born children / } \\
\text { Overcrowding }\end{array}$ & $\begin{array}{c}\text { Sewerage system / } \\
\text { Water }\end{array}$ \\
\hline School attendance & - & $\begin{array}{l}\text { Sewerage } \\
\text { system }\end{array}$ & Child labour & $\begin{array}{l}\text { Deaths of } \\
\text { live-born } \\
\text { children }\end{array}$ & $\begin{array}{c}\text { Deaths of } \\
\text { live-born children / } \\
\text { Sewerage system }\end{array}$ \\
\hline Overcrowding & - & $\begin{array}{l}\text { Sewerage } \\
\text { system }\end{array}$ & $\begin{array}{l}\text { Deaths of } \\
\text { live-born } \\
\text { children }\end{array}$ & School attendance & $\begin{array}{l}\text { Sewerage system / } \\
\text { Deaths of } \\
\text { live-born children }\end{array}$ \\
\hline Child labour & - & $\begin{array}{l}\text { Sewerage } \\
\text { system }\end{array}$ & School attendance & $\begin{array}{l}\text { School attendance / } \\
\text { Sewerage system }\end{array}$ & $\begin{array}{c}\text { Deaths of } \\
\text { live-born children }\end{array}$ \\
\hline Assets & - & $\begin{array}{l}\text { Functional } \\
\text { illiteracy }\end{array}$ & Sewerage system & $\begin{array}{l}\text { Functional illiteracy / } \\
\text { Unemployed adults }\end{array}$ & $\begin{array}{l}\text { Sewerage system / } \\
\text { Functional illiteracy }\end{array}$ \\
\hline Self-evaluation of health status & - & $\begin{array}{l}\text { Sewerage } \\
\text { system }\end{array}$ & $\begin{array}{l}\text { Deaths of } \\
\text { live-born } \\
\text { children }\end{array}$ & $\begin{array}{l}\text { Sewerage system / } \\
\text { Deaths of live-born } \\
\text { children }\end{array}$ & $\begin{array}{c}\text { Disposal of household } \\
\text { waste }\end{array}$ \\
\hline Water & $\begin{array}{l}\text { Sewerage } \\
\text { system }\end{array}$ & None & $\begin{array}{l}\text { Sewerage system / } \\
\text { Deaths of } \\
\text { live-born children }\end{array}$ & $\begin{array}{l}\text { Sewerage system / } \\
\text { Disposal of } \\
\text { household waste }\end{array}$ & $\begin{array}{l}\text { Sewerage system / } \\
\text { Child labour }\end{array}$ \\
\hline Functional illiteracy & - & Assets & Sewerage system & $\begin{array}{l}\text { Deaths of } \\
\text { live-born } \\
\text { children }\end{array}$ & $\begin{array}{c}\text { Sewerage system / } \\
\text { Assets }\end{array}$ \\
\hline Unemployed adults & - & $\begin{array}{l}\text { Assets/ } \\
\text { Functional } \\
\text { illiteracy }\end{array}$ & Assets & Functional illiteracy & $\begin{array}{c}\text { Deaths of } \\
\text { live-born children }\end{array}$ \\
\hline Fuel used for cooking & $\begin{array}{l}\text { Sewerage } \\
\text { system }\end{array}$ & - & $\begin{array}{l}\text { Sewerage system / } \\
\text { Deaths of } \\
\text { live-born children }\end{array}$ & $\begin{array}{l}\text { Deaths of } \\
\text { live-born } \\
\text { children }\end{array}$ & $\begin{array}{l}\text { Sewerage system / } \\
\text { Disposal of } \\
\text { household waste }\end{array}$ \\
\hline Material that walls are made of & $\begin{array}{l}\text { Sewerage } \\
\text { system }\end{array}$ & - & $\begin{array}{l}\text { Sewerage system / } \\
\text { Deaths of } \\
\text { live-born children }\end{array}$ & $\begin{array}{l}\text { Sewerage system / } \\
\text { Disposal of } \\
\text { household waste }\end{array}$ & Overcrowding \\
\hline
\end{tabular}

Source: prepared by the authors on the basis of Brazilian Geographical and Statistical Institute (IBGE), 2008 national household survey.

as those that combine "disposal of household waste", "deaths of live-born children" and "overcrowding", or those that combine "school attendance", "deaths of liveborn children" and "sewerage system" or "overcrowding", "sewerage system" and "deaths of live-born children", as well as others. This points to the existence of negative inter-indicator synergies associated with multidimensional forms of deprivation.

The absolute levels of deprivation for each indicator, as detailed in the upper portion of table 5, have an influence on these results, however. For many households, the relative lack of a sewerage system coincides with an instance 
of deprivation measured by some other indicator, since the former is the most numerically significant result of all. The results that do not display a level of frequency in absolute terms (i.e., indicators that are more likely to appear in combination with others than alone) are shown in table 6. For example, although the number of households that lack running water is not numerically significant, the two-dimensional "sewerage system-running water" indicator is significant. Another case in point is the combination of child labour and school attendance, for which the absolute values are also more significant than the values for either one of those indicators alone. In yet another case, while the absence of assets and the presence of functional illiterates and unemployed adults in the household are not significant as stand-alone indicators, the combination of those three indicators is.

The results shown in table 6 indicate that some indicators of deprivation tend to be more significant when considered in combination with two or three other dimensions than when they are considered individually. In order to gain a better understanding of these relationships, a factor analysis was undertaken (see table 7) in order to check whether a positive correlation actually does exist among these indicators (e.g., to determine if households lacking a sewerage system also tended to lack a hook-up to a water distribution system).
The factor analysis of the profiles highlighted in table 6 confirmed some of the results presented earlier, since it yielded different groups of indicators. For ease of interpretation, the indicators "sewerage system" and "water" were grouped into a single dimension under the heading "urban features" and the indicators "child labour" and "school attendance" were grouped into a dimension under the heading of "children". Three other indicators ("unemployed adults", "functional illiteracy" and "assets") were grouped under the heading of "unskilled, low-income adults". The factor analysis also turned up another grouping of indicators of low socioeconomic status which was not apparent in table 6 because of the small number of observations ("main material used in the construction of the external walls of the dwelling" and "fuel used for cooking").

The indicators "number of deaths of live-born children", "disposal of household waste", "self-evaluation of health status" and "overcrowding" are relatively independent of the others and are not grouped with other indicators. This suggests that policies aimed at reducing multidimensional poverty should be focused on existing inter-indicator synergies. For example, skills training for adults with low levels of schooling would probably have a positive impact on the indicators for "functional illiteracy" and "assets".

TABLE 7

Dimensions grouped on the basis of the factor analysis

1. Urban features

Sanitation services or sewerage systems and running water in the home

2. Children

Child labour and school attendance

3. Unskilled low-income adults

Unemployed adults, functional illiterates and assets in the home

4. Very low socioeconomic status - similar to rural environment

Main material used in the construction of the dwelling's external walls and fuel used for cooking

5. Number of deaths of live-born children

6 Disposal of household waste

7 Self-evaluation of health status

8 Overcrowding

Source: prepared by the authors. 


\section{V \\ Comparison of monetary and multidimensional indices at the regional level}

This section will compare measurements of multidimensional poverty and measurements of poverty based on a monetary metric in the states of Brazil. To this end, definitions will be needed of what constitutes monetary and nonmonetary deprivation.

We first define poverty from a monetary standpoint. Household incomes in 2003 - i.e., the sum of the incomes of all members of the household - were divided by the number of people in the household in order to arrive at the per capita household income. This value was then divided by the minimum wage ( 240 reais) as of September 2003 (the reference date for that year). This yielded a figure for per capita household income expressed in units of the minimum wage for September 2003 for all Brazilian households. Members of households in which that income figure was below $50 \%$ of the minimum wage were defined as poor. This threshold figure has been used by the government in the design of its social programmes and policies and is commonly used in studies on poverty in Brazil (see, for example, World Bank, 2006, and, for a detailed analysis of the setting of the poverty line in Brazil, see Rocha, 2003). This same procedure was followed to process the data for 2008 , with these values being adjusted by the consumer price index (CPI) of the Brazilian Geographical and Statistical Institute for purposes of comparison with the values for September 2003.

According to the definition used here, $27 \%$ and $16.1 \%$ of urban dwellers in Brazil were poor in 2003 and 2008, respectively, which represents a considerable reduction in monetary poverty over this time span. For the measurement of multidimensional poverty, a distinction was drawn between households that were not experiencing deprivation and those that were doing so in respect of at least one of the 13 indicators.

Figures 1 and 2 show how monetary poverty compares with the results presented in table 4 for persons experiencing deprivation as measured by at least one indicator in 2003 and 2008. Because the percentage of people defined as poor using the income-based measurement and using the MDI are similar when at least two deprivation indicators are registered, this arbitrary

FIGURE 1

Brazil (urban areas): percentage of people living in poverty as measured by monetary and multidimensional indices, 2003

(Percentages)

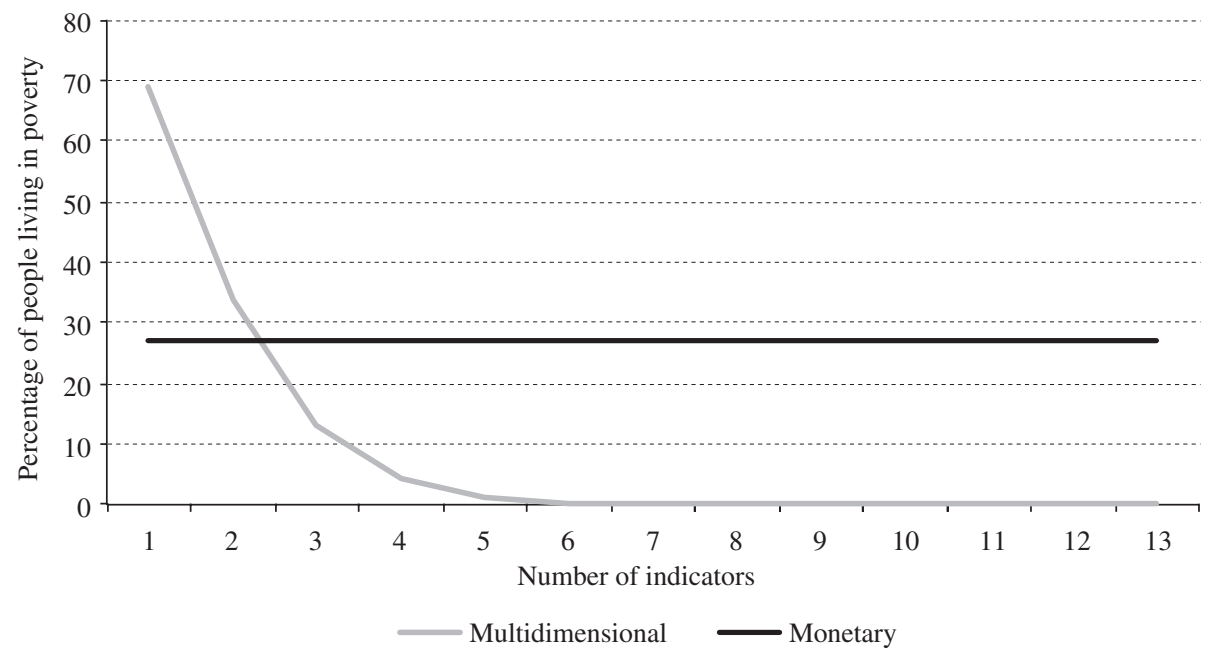

Source: prepared by the authors on the basis of Brazilian Geographical and Statistical Institute (IBGE), 2003 national household survey. 


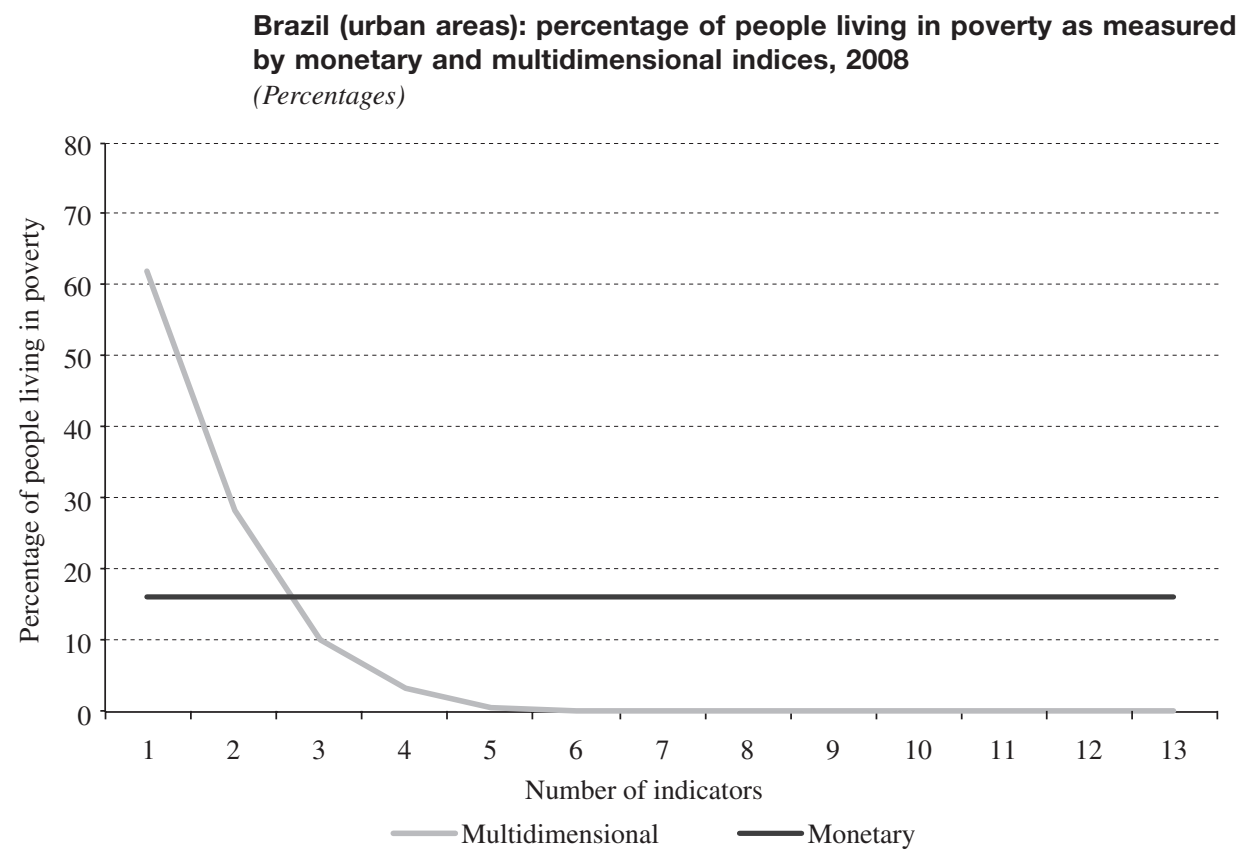

Source: prepared by the authors on the basis of Brazilian Geographical and Statistical Institute (IBGE), 2008 national household survey.

number was used to classify the households. Thus, those that experience deprivation as measured by two or more indicators will be classified as poor using the multidimensional measurement.

The following graphs map the distribution of monetary and non-monetary poverty in the states of Brazil. Maps 1 and 2 show the distribution of income poverty for 2003 and 2008, respectively, while the distribution of multidimensional poverty for those same years is shown in maps 3 and 4 .

Maps 1 and 2 indicate that the states in which the largest percentages of people were experiencing deprivation in both of the years under study, according to the monetary measurement of poverty, were Alagoas, Ceará, Maranhão, Paraíba, Pernambuco and Piauí, in the north-east, while those in which the smallest percentages of people were experiencing deprivation were in the southern and south-eastern states of Paraná, Rio de Janeiro, Rio Grande do Sul, Santa Catarina and São Paulo. The differing and increasing levels of poverty as one moves from southern Brazil to its northern and north-eastern regions is evident in both years. The maps also point to a reduction in poverty in all the states of the federation over time.

Maps 3 and 4 show the proportion of people who are living in households experiencing deprivation in terms of at least two of the variables measured by the indicators. The highest relative values for non-monetary measures of deprivation (over 70\% in 2003 and 50\% in 2008) correspond to four states in the north and northeast of the country: Amapá, Pará, Piauí and Rondônia. The values for the Federal District, Minas Gerais and São Paulo, on the other hand, are below $25 \%$ and $20 \%$ in 2003 and 2008, respectively. The highest figures correspond to the northern, north-eastern and centralwestern regions of the country. The settlement of these areas, especially the zones along the southern and eastern borders of the Amazon jungle, is quite recent, and the production of agricultural commodities for export in these areas is steadily increasing, but the cities in these zones are still not fully developed. The variables associated with the greatest deprivation have to do with urban services (running water, sewerage systems and systems for the disposal of household waste, etc.). The sharp reduction in multidimensional poverty seen in the majority of the states during the period under study is nonetheless remarkable.

The maps reflect the socioeconomic inequalities existing in Brazil, as well as the sizeable reduction in both monetary poverty and multidimensional deprivation in many states, and the marked changes in the monetary and non-monetary indicators during this period. 
MAP 1

Brazil (urban areas): percentage of income poverty, 2003 (Percentages)

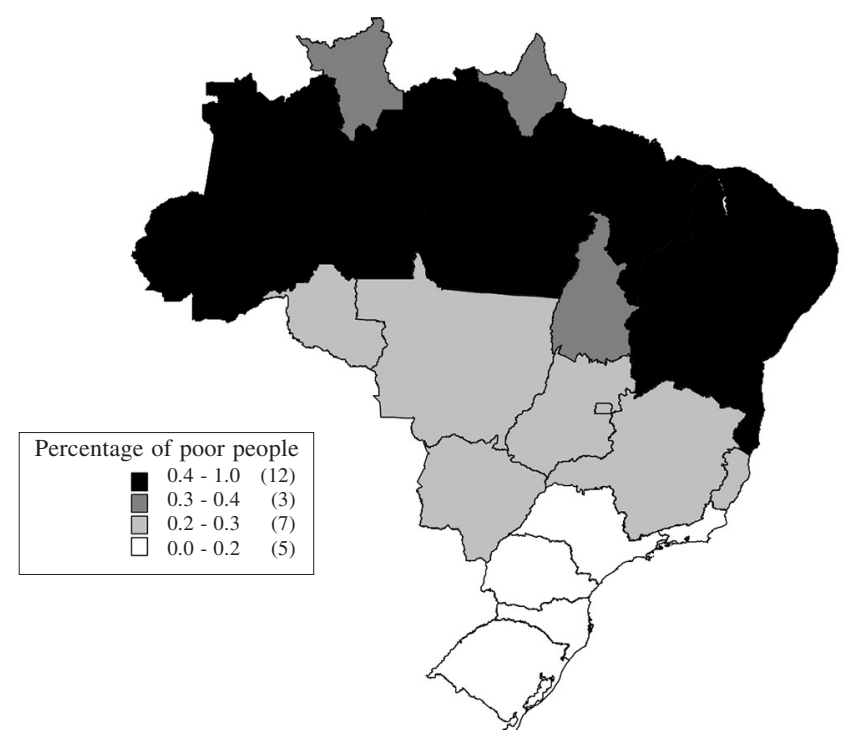

Source: prepared by the authors on the basis of Brazilian Geographical and Statistical Institute (IBGE), 2003 national household survey. Note: the numbers shown in brackets indicate the number of states exhibiting a given poverty rate.

MAP 2

Brazil (urban areas): percentage of income poverty, 2008 (Percentages)

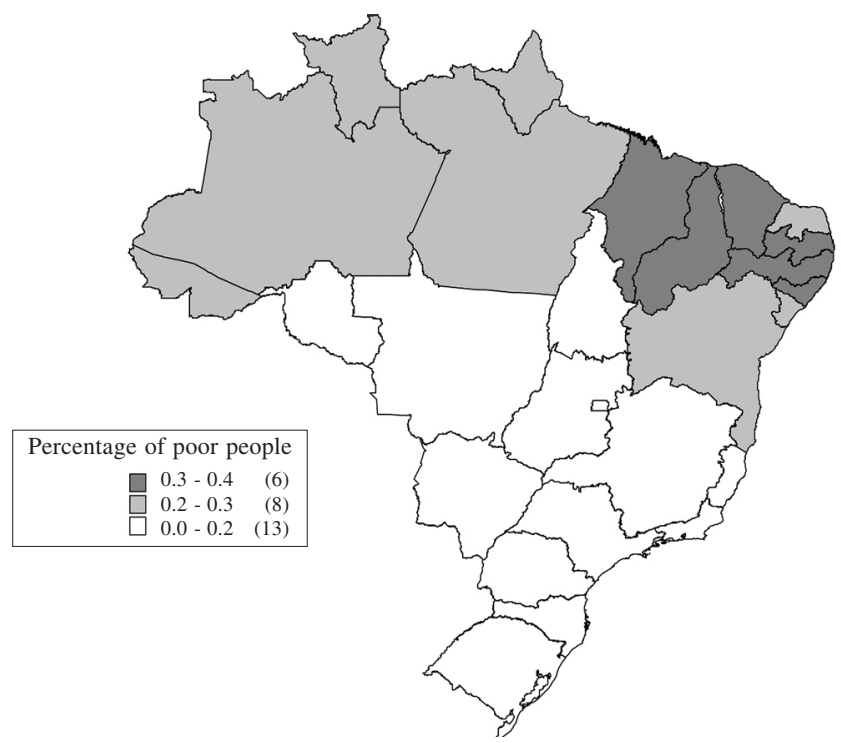

Source: prepared by the authors on the basis of Brazilian Geographical and Statistical Institute (IBGE), 2008 national household survey. Note: the numbers shown in brackets indicate the number of states exhibiting a given poverty rate. 
MAP 3

Brazil (urban areas): percentage of households registering at least two indicators of deprivation, 2003

(Percentages)

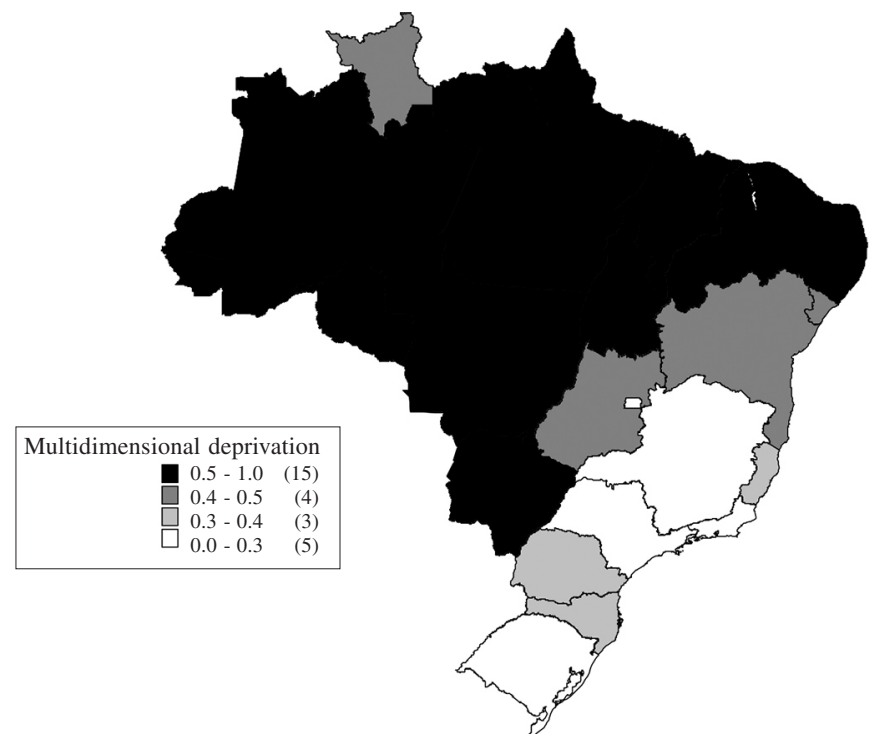

Source: prepared by the authors on the basis of Brazilian Geographical and Statistical Institute (IBGE), 2003 national household survey. Note: the numbers shown in brackets indicate the number of states falling within a specified range of poverty rates.

MAP 4

Brazil (urban areas): percentage of households registering at least two indicators of deprivation, 2008

(Percentages)

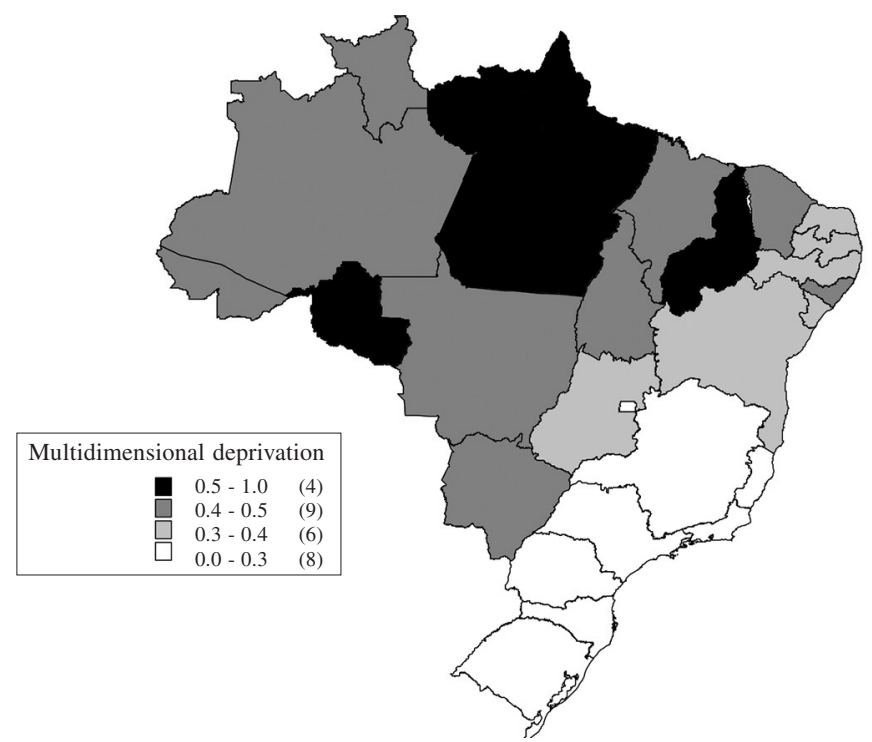

Source: prepared by the authors on the basis of Brazilian Geographical and Statistical Institute (IBGE), 2008 national household survey. Note: the numbers shown in brackets indicate the number of states falling within a specified range of poverty rates. 
Table 8 shows the correlation between these indicators, which, as the reader will see, are all positive and significant at $5 \%$. When the same indicator is compared for two different years, there is a strong correlation (both over 95\%), whereas the correlation of the values for the monetary and multidimensional indicators is much lower (around 60\%). What is more, the weaker correlation between the multidimensional indicator and the income-based indicator for 2008 points to an increase in the differences between the two types of metrics.

The last sections provide an overall picture of the MDI and present an analysis of some of the specific features of each dimension of deprivation and their common aspects and interrelationships, along with comparisons of these dimensions with monetary poverty. Generally speaking, the results indicate that multidimensional deprivation in Brazil declined between 2003 and 2008, for two reasons: a decrease in the relative number of people living in poor households and, among those living in households that were experiencing deprivation, an increase in the number for which that deprivation corresponded to only one indicator. Monetary poverty also declined during the period under study.

The results of these indicators reflect a shifting pattern. Section VI draws on synthetic cohorts and econometric models in order to paint a more detailed picture of the pattern of deprivation.

TABLE 8

Correlation between income-based poverty and multidimensional deprivation

\begin{tabular}{lccc}
\hline Indicators & $\begin{array}{c}\text { Monetary poverty } \\
\text { in 2003 }\end{array}$ & $\begin{array}{c}\text { Monetary poverty } \\
\text { in 2008 }\end{array}$ & $\begin{array}{c}\text { Multidimensional poverty } \\
\text { in 2003 }\end{array}$ \\
\hline Monetary poverty in 2008 & 0.98 & - & - \\
Multidimensional deprivation in 2003 & 0.69 & 0.62 & - \\
Multidimensional deprivation in 2008 & 0.59 & 0.52 & 0.96 \\
\hline
\end{tabular}

Source: prepared by the authors on the basis of Brazilian Geographical and Statistical Institute (IBGE), 2003 and 2008 national household surveys.

\section{VI}

\section{Analysis of patterns of deprivation based on synthetic cohorts}

This section draws on synthetic cohorts and econometric models inspired by age-period-cohort models (BenSchlomo and Kuh, 2002; Reither, Hauser and Yang, 2009; Yang, 2007, 2008a and 2008b; Yang and Lee, 2009) to look at patterns of deprivation. More specifically, an effort is made to answer the following questions: are monetary poverty and multidimensional deprivation distributed differently among the various population groups? Are the same trends seen over time in these groups as measured by these indicators?

Given the absence of longitudinal data, synthetic cohorts defined on the basis of certain characteristics of heads of household were used instead. While the cohorts do not include all the same people, the database is representative of the national population, so the synthetic cohorts are representative of the same population groups in the two periods and can be used to undertake a point analysis of the time trend. In other words, the individual longitudinal data can be equated with the representative homogeneous cohort data.

The synthetic cohorts were classified on the basis of homogeneous groups using four variables: race or colour (white or black), sex (male or female), age group (20-29, 30-39, 40-49, 50-59 and 60-69 years in 2003 and five years older than that in 2008) and years of formal schooling (0, 1-3, 4-7, 8-10, 11 and 12 years or more). These categories $(2 \times 2 \times 5 \times 6)$ yielded 120 synthetic cohorts. In order to ensure that these groups would be as homogeneous and as representative as possible, a minimum threshold of 50 observations was set for each 
group in each year. Thus, the parameters were set to take into account the trade-off between homogeneity and representativeness.

The features used to define the synthetic cohorts are such that very similar groups can be selected for the two years in question. A change in the sex of the people concerned is extremely rare, but changes in race or colour are more common, since this variable is defined by the respondents, who may change their mind as to their race or colour. Most of the heads of household were over 20 years of age and their level of formal schooling did not change in terms of the categories defined for this purpose. While international migration may have some effect on the composition of the urban population, the size of this change relative to the population of Brazil is minimal.

We determined whether the heads of household in all of the homogeneous groups belonged to a household classified as poor on the basis of the monetary metric and then classified them according to the number of deprivation indicators that they registered. Table 9 shows which population groups displayed the greatest propensity to monetary or multidimensional poverty. A number of trends stand out clearly: poverty or deprivation as defined by the two metrics tends to be greater among households headed by persons of African descent than among households headed by other persons and to be greater among female-headed households than male headed households. The values for the three indicators for white male heads of household are below average for both years, whereas the values for all other categories were above the average (signalling a greater propensity to monetary and multidimensional poverty). The values of both types of poverty indicators were lower in 2008 than in 2003.

The monetary metric indicates that there were relatively fewer poor households in the older age cohorts for both years. The trend in terms of deprivation as measured by at least one indicator is unclear, since all the cohorts register similar values (around 70\%). As far as the levels of deprivation that are measured by at least two indicators, similar values are obtained for the four youngest cohorts in 2003 and for the first three in 2008. The highest values corresponded to the members of the older cohorts, and the differences increased over the time span in question.

Higher levels of schooling are associated with lower levels of poverty or deprivation in both years and in relation to all the variables, but this is especially true in the case of monetary poverty. The values for 2008 are also lower than the values for 2003 , which points to a

TABLE 9

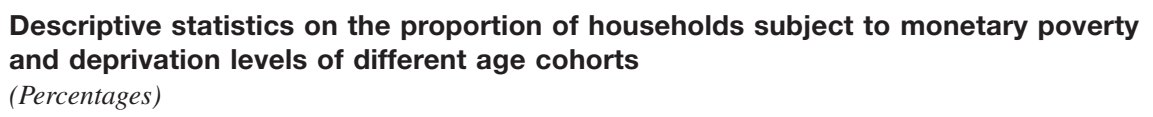

Descriptive statistics on the proportion of households subject to monetary poverty and deprivation levels of different age cohorts (Percentages)

\begin{tabular}{|c|c|c|c|c|c|c|}
\hline \multirow{2}{*}{ Categories } & \multicolumn{2}{|c|}{ Monetary poverty } & \multicolumn{2}{|c|}{$\begin{array}{l}\text { Deprivation as measured by } \\
\text { at least one indicator }\end{array}$} & \multicolumn{2}{|c|}{$\begin{array}{l}\text { Deprivation as measured by } \\
\text { at least two indicators }\end{array}$} \\
\hline & 2003 & 2008 & 2003 & 2008 & 2003 & 2008 \\
\hline Total & 28.0 & 16.3 & 71.0 & 66.8 & 36.9 & 34.4 \\
\hline White & 17.8 & 9.4 & 67.4 & 63.3 & 33.2 & 31.2 \\
\hline Black & 39.2 & 22.8 & 74.6 & 70.3 & 40.7 & 37.6 \\
\hline Male & 27.0 & 15.0 & 69.1 & 64.0 & 34.1 & 31.7 \\
\hline Female & 31.2 & 18.9 & 72.8 & 69.6 & 39.7 & 37.1 \\
\hline \multicolumn{7}{|c|}{ Cohorts (age in 2003) } \\
\hline $20-29$ & 38.4 & 23.8 & 71.1 & 67.5 & 36.4 & 32.3 \\
\hline $30-39$ & 33.7 & 19.4 & 71.1 & 66.6 & 35.9 & 31.7 \\
\hline $40-49$ & 26.2 & 13.6 & 71.4 & 64.9 & 36.2 & 32.3 \\
\hline $50-59$ & 21.4 & 10.9 & 69.7 & 65.9 & 35.6 & 34.6 \\
\hline $60-69$ & 18.4 & 6.5 & 71.7 & 69.1 & 40.5 & 41.1 \\
\hline \multicolumn{7}{|c|}{ Level of schooling (years) } \\
\hline 0 & 54.1 & 33.4 & 80.3 & 76.9 & 51.5 & 46.2 \\
\hline 1 to 3 & 42.9 & 27.9 & 79.7 & 79.8 & 51.6 & 47.1 \\
\hline 4 to 7 & 31.7 & 19.3 & 74.0 & 70.5 & 40.2 & 35.4 \\
\hline 8 to 10 & 22.1 & 15.0 & 65.8 & 64.7 & 29.4 & 28.7 \\
\hline 11 & 10.6 & 7.1 & 63.0 & 58.4 & 24.7 & 20.9 \\
\hline 12 an over & 3.2 & 2.4 & 63.7 & 55.0 & 21.1 & 15.6 \\
\hline
\end{tabular}

Source: prepared by the authors on the basis of Brazilian Geographical and Statistical Institute (IBGE), 2003 and 2008 national household surveys. 
positive trend in the three indicators. The improvement in the indicators for monetary poverty was stronger than it was for the other indicators.

Table 9 provides an overall view of the results, but in order to take a closer look at the effect that the various variables have on levels of deprivation, we turned to econometric models and used three dependent variables: monetary poverty, deprivation as measured by at least one indicator and deprivation as measured by at least two indicators. The independent variables are: a dummy variable for sex ( 1 for male, 0 for female), a dummy variable for race/colour (1 for white, 0 for black), dummy variables for cohorts (the youngest cohort was used as a point of reference), five dummy variables for levels of schooling (the least-educated group was used as a point of reference) and a dummy variable for the year (1 for 2008, 0 for 2003).

The analysis of the synthetic cohorts was based on four models which were estimated using the ordinary least squares (OLS) method. The first corresponded to the data for 2003 and the second to data for 2008. The third referred to aggregate data (an analysis similar to an analysis of panel data with random effects) and the fourth to the variations between the values for 2003 and 2008.

Table 10 shows the results, which confirm some of the general trends noted in the first three models and the three dependent variables. Monetary poverty and deprivation as measured by the other indicators are more prevalent in households headed by persons of African descent and by women, even when other variables are controlled for.

People of African descent have historically been overrepresented in the low-income and most deprived sectors of the Brazilian population. One - and perhaps the most important- explanatory variable for this is the education gap them and the rest of the population. The policies that have been applied in recent years in Brazil have made primary education almost universal, have opened up access to secondary education and have boosted the number of people attending private schools, while affirmative action policies have had the same kind of effect in the country's universities. Nonetheless, the children of lower-income people still often attend poorer-quality primary schools, and their lower level of education hinders them from achieving meaningful social advancement.

An analysis of these results yielded coefficients that were either not significant or very weakly so. The coefficients for race were positive and statistically significant for both monetary poverty and deprivation as measured by at least two indicators, but were not significant for the model for deprivation as measured by a at least one indicator. This suggests that households headed by persons of African descent exhibit a pattern of monetary poverty that is similar to the pattern displayed by other households but that the level of deprivation was slightly higher for the former, especially in terms of multidimensional forms of deprivation.

In the case of female-headed households, the statistically significant negative coefficients recorded for the first three models come as no surprise. The absence of a spouse in the majority of these households is one of the reasons for their low incomes. Households in which there is a couple, many of which have at least two sources of income, tend to be headed by males. When households headed by single males or females are compared, the differences are much smaller. The last model, which is the framework for an analysis of differences in indicators over time, yielded statistically significant negative coefficients for deprivation as measured by at least one indicator; the results in all other cases were not statistically significant. Even though the results suggest that female-headed households are worse off in respect of this indicator, in this case a slight trend towards the levelling of non-monetary deprivation is observed. The social policies recently implemented in Brazil (e.g., policies that have increased six-year-olds' access to schooling), which have been particularly effective for these types of households, may have exerted a positive effect in this respect.

Regardless of the dependent variable concerned, the same trend in terms of level of education becomes apparent. The lower the level of schooling, the higher the percentage of households experiencing deprivation. While these results were to be expected, the temporal trends differ. As can be seen from the last model, even though a higher level of schooling is associated with a lower rate of monetary poverty, households with higher levels of education had a greater propensity to experience deprivation. This result can be attributed, in part, to the overall increase in levels of education in Brazil, the reduction in income inequality brought about by conditional cash transfer policies (such as those underlying the Brazilian Family Benefit (Bolsa Familia) Programme and the Continuing Benefit (Benefício de Prestação Continuada) Programme) and changes in the labour market. On the other hand, the widening in these differences in respect of the relative level of deprivation as measured by at least indicator, especially in households headed by persons who have some higher education, suggests that people with more schooling have greater success in avoiding non-monetary forms of deprivation. 
TABLE 10

Analysis of values and variations of econometric models estimated using synthetic cohorts

\begin{tabular}{|c|c|c|c|c|c|}
\hline \multirow{2}{*}{ Variables } & & \multicolumn{3}{|c|}{ Value } & \multirow{2}{*}{ Difference } \\
\hline & & 2003 & 2008 & Aggregate data & \\
\hline \multicolumn{6}{|c|}{ Monetary poverty } \\
\hline $\begin{array}{l}\text { Constant } \\
\text { Race } \\
\text { Sex }\end{array}$ & & $\begin{array}{r}0.80 \\
-0.11 \\
-0.05\end{array}$ & $\begin{array}{r}0.56 \\
-0.07 \\
-0.04\end{array}$ & $\begin{array}{r}0.74 \\
-0.09 \\
-0.04\end{array}$ & $\begin{array}{r}-0.24 \\
0.04 \\
\mathbf{0 . 0 1}\end{array}$ \\
\hline $\begin{array}{l}\text { Level of schooling } \\
\text { (years of formal education) }\end{array}$ & $\begin{array}{l}1-3 \\
4-7 \\
8-10 \\
11 \\
12 \text { or more }\end{array}$ & $\begin{array}{l}-0.11 \\
-0.24 \\
-0.34 \\
-0.45 \\
-0.52\end{array}$ & $\begin{array}{l}-0.07 \\
-0.18 \\
-0.22 \\
-0.29 \\
-0.33\end{array}$ & $\begin{array}{l}-0.09 \\
-0.21 \\
-0.28 \\
-0.37 \\
-0.43\end{array}$ & $\begin{array}{l}0.04 \\
0.06 \\
0.12 \\
0.16 \\
0.19\end{array}$ \\
\hline Cohort (age en 2003) & $\begin{array}{l}30-39 \\
40-49 \\
50-59 \\
60-69\end{array}$ & $\begin{array}{l}-0.05 \\
-0.16 \\
-0.24 \\
-0.30\end{array}$ & $\begin{array}{l}-0.09 \\
-0.17 \\
-0.23 \\
-0.28\end{array}$ & $\begin{array}{l}-0.07 \\
-0.16 \\
-0.23 \\
-0.29\end{array}$ & $\begin{array}{r}-0.04 \\
\mathbf{- 0 . 0 2} \\
\mathbf{0 . 0 1} \\
\mathbf{0 . 0 2}\end{array}$ \\
\hline Year (2003) & & - & - & -0.12 & - \\
\hline
\end{tabular}

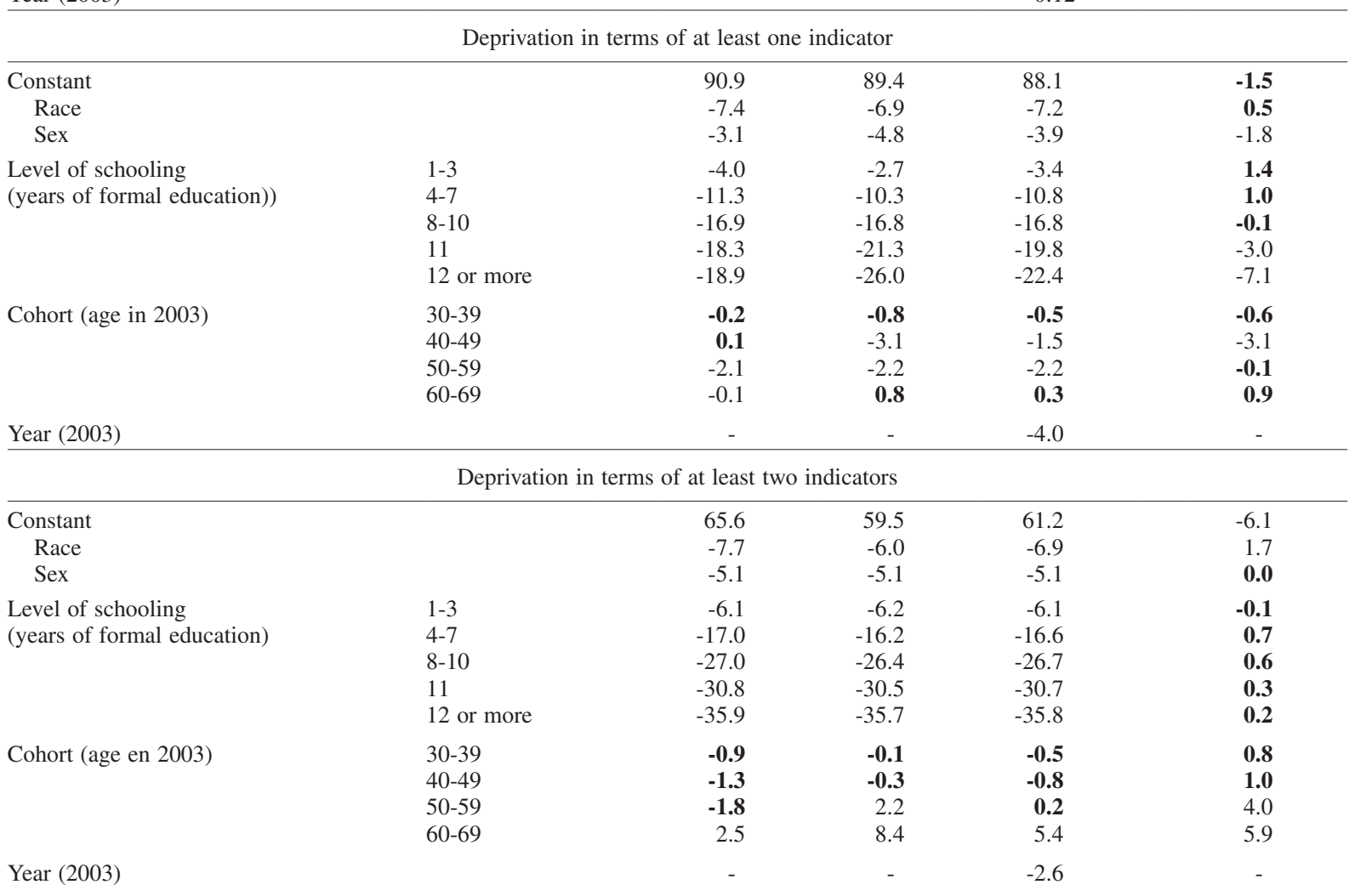

Source: prepared by the authors on the basis of Brazilian Geographical and Statistical Institute (IBGE), 2003 and 2008 national household surveys.

Note: the coefficients shown in bold are not significant. 
The relative results for the various cohorts differ depending on which dependent variable is used. The trends for income poverty are clear-cut: the older the age cohort, the lower the propensity to this type of poverty. This result is reflected in the fact that younger people have less success in entering the labour market, which may be linked to recent trends in school drop-out rates and in drug abuse associated with the crack epidemic.

Many of the coefficients for deprivation as measured by at least one indicator were not significant, and the corresponding profile is therefore slightly different from the profile for income poverty in terms of both values and differences. Although age is a factor in the type of deprivation being experienced, the differences are not very large for people experiencing non-monetary deprivation. When deprivation as measured by at least two indicators was analysed, on the other hand, the values were higher for older cohorts, which suggests that multidimensional deprivation is more common among older adults, and the differences increased over the period under study.

\section{VII}

\section{Final remarks and conclusions}

Using the capability approach as a theoretical frame of reference, a multidimensional deprivation index (MDI) was developed for Brazil and the individual Brazilian states for 2003 and 2008. The construction of this index, which was inspired by the methodology developed by Alkire and Santos (2010), was based on four dimensions (living conditions, health, level of education and participation in the labour market) and 13 indicators. The MDI was then used to analyse deprivation from various standpoints in an effort to obtain a more complete, multidimensional picture of deprivation in urban areas of Brazil.

The results indicate that a majority of the population segment in question lives in households that are not experiencing non-monetary deprivation or are experiencing deprivation only in terms of one of the indicators. Households registering deprivation as measured by many different indicators made up no more than a small proportion of the sample. The relative number of people living in households experiencing deprivation also declined over the study period and, among those that were already deprived, the proportion that were registering deprivation in terms of a single indicator increased.

The common features and relationships among the indicators were examined by means of a factor analysis. Some aspects of deprivation may show up in two or more indicators, such as: water and sewerage systems, child labour and school non-attendance, and the presence of assets, unemployed adults and functional illiterates in the home. The results thus suggest that policies aimed at reducing multidimensional situations of deprivation should also target the synergies that may exist among the different dimensions.

A comparison of income poverty and multidimensional deprivation in the states of Brazil showed up regional inequalities as reflected in these two metrics. It is noteworthy that both monetary poverty and multidimensional deprivation decreased considerably in the great majority of states. There was very little correlation, however, between the indicators for monetary and non-monetary deprivation.

Finally, patterns of deprivation were examined using synthetic cohorts and oLs models. This approach made it possible to analyse the relationship between attributes such as sex, race, year of birth and level of education of the head of household, on the one hand, and, on the other, a household's propensity to become or remain in a state of deprivation.

Both monetary and non-monetary forms of deprivation are found more often in households headed by persons of African descent, women, persons lacking in vocational skills and young people, even after controlling for the other variables. Trends over time for the various indicators also differed.

The results show that an increase in the level of schooling reduces both monetary and non-monetary deprivation. However, education became a less important factor in terms of the first of these indicators over the study period. This may be attributable, in part, to the overall increase in levels of education and the decrease seen in income inequality in Brazil.

The results regarding cohorts are not neutral for the dependent variable. In the case of monetary poverty, the 
trend is clear-cut: the propensity towards deprivation is lower in older cohorts. This may be reflecting a lower rate of successful entry into the labour market for younger generations.

In the case of deprivation as measured by at least one indicator, even though age has an effect on the type of deprivation concerned, no major differences are apparent with respect to people experiencing nonmonetary forms of deprivation. Our understanding of this aspect of the situation may benefit from further research in the future. On the other hand, the analysis of deprivation as measured by at least two indicators demonstrates that the values are higher for older cohorts, suggesting that multidimensional deprivation is more prevalent among older adults. These cohorts also tend to be faced with specific types of problems relating to multidimensional deprivation which could also be researched in greater depth.

The evidence compiled in this study indicates that the non-monetary multidimensional metric can capture deprivation-related and welfare-related aspects that are not captured with a monetary-based metric. For example, a household that is classified as poor in monetary terms may not be considered to be poor when viewed from the standpoint of other measurements, such as that of multidimensional deprivation. Deprivation, defined as insufficient well-being, should be assessed on the basis of both monetary and non-monetary variables (Bourguignon and Chakravarty, 2003; Thorbecke, 2005). This study has been conducted in an effort to help to arrive at a fuller, multidimensional picture of deprivation in urban areas of Brazil and to suggest some promising areas for future research.

\section{APPENDIX}

As shown in map A.1, Brazil is one of the largest countries in the world, with a territory stretching over more than 8 million square kilometres. Its five macro-regions (the northern, north-eastern, south-eastern, southern and centralwestern regions) are divided into 26 states plus the Federal District.

MAP A.1

\section{Political map of Brazil, 2008}

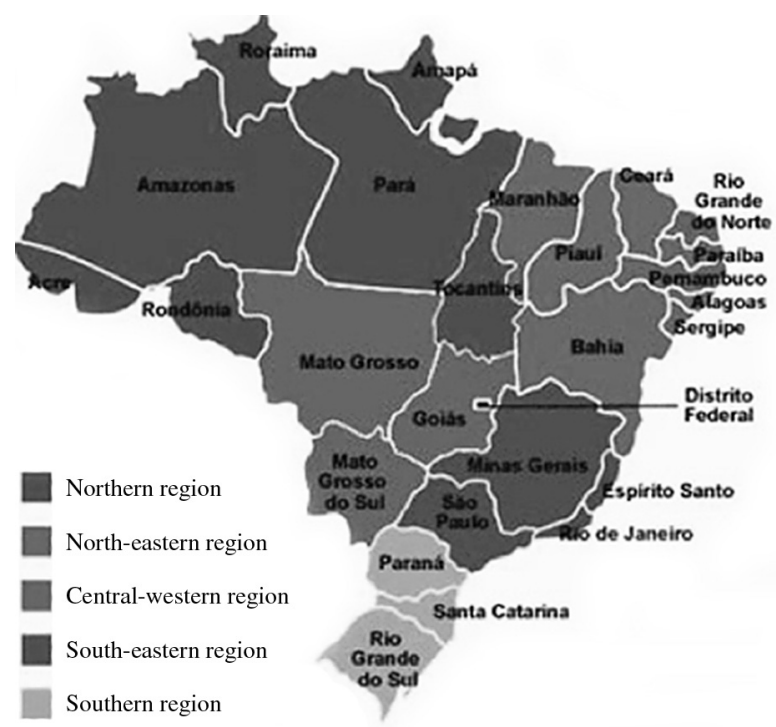

Source: http://www.Brazil-turismo.com/geografia.htm 
Alkire, S. and J. Foster (2007), "Counting and multidimensional poverty measurement", OPHI Working Paper, No. 32, Oxford, Oxford Poverty and Human Development Initiative [online] http://www.ophi.org.uk/wp-content/uploads/oPHI-wp32.pdf.

Alkire, S. and M. Santos (2010), "Acute multidimensional poverty: a new index for developing countries", Human Development Research Papers, No. 2010/11, New York, Human Development Report Office, United Nations Development Programme.

Atkinson, A. (2003), "Multidimensional deprivation: contrasting social welfare and counting approaches", Journal of Economic Inequality, vol. 1, No. 1, Springer.

Bagolin, I. and R. Ávila (2006), "Poverty distribution song the Brazilian states: a multidimensional analysis using capabilities and needs approaches", Anais do XXXIV Encontro Nacional de Economia, Rio de Janeiro, National Association of Postgraduate Centers in Economics.

Baulch, B. and E. Masset (2003), "Do monetary and non-monetary indicators tell the same story about chronic poverty? A study of Vietnam in the 1990s", World Development, vol. 31, No. 3, Amsterdam, Elsevier.

Ben-Schlomo, Y. and D. Kuh (2002), "A life course approach to chronic disease epidemiology: conceptual models, empirical challenges, and interdisciplinary perspectives", International Journal of Epidemiology, vol. 31, No. 2, Oxford, Oxford University Press.

Bourguignon, F. and S. Chakravarty (2003), "The measurement of multidimensional poverty", Journal of Economic Inequality, vol. 1, No. 1, Springer.

D’Ambrosio, C. and R. Rodrigues (2008), "Deprivation in the São Paulo districts: evidence from 2000", World Development, vol. 36, No. 6, Amsterdam, Elsevier.

Decancq, K. and M. Lugo (2010), "Weights in multidimensional indices of well-being: an overview", Center for Economic Studies - Discussion Papers, No. CES10.06, Louvain, Catholic University of Louvain.

Ferreira, F. and A. Lugo (2012), "Multidimensional poverty analysis: looking for a middle ground", Policy Research Working Paper, No. 5964, Washington, D.C., World Bank.

Golgher, A.B. (2010a), "Perceived deprivation in Brazil in a multidimensional perspective", Revue d'économie régionale et urbaine, No. 2, Paris, Editions NecPlus.

(2010b), "Multidimensional poverty in Brazil: income, assets and expenses", paper presented at the 57th Annual North American Meetings of the Regional Science Association International, Denver.

(2009), "Poverty in Brazil: income, material hardship and the perception of deprivation", paper presented at the Population Association of America Annual Meeting, Detroit.

IBGE (Brazilian Geographical and Statistical Institute) (2008), Pesquisa Nacional por Amostra de Domicílios 2008, Rio de Janeiro.

(2003), Pesquisa Nacional por Amostra de Domicílios 2003, Rio de Janeiro.

Lopes, H., P. Macedo and A. Machado (2004), "Análise multidimensional de pobreza para as meso e microrregiões de Minas Gerais" [online] http://www.cedeplar.ufmg.br/diamantina2004/textos/ D04A014.PDF.
(2003), "Indicador de pobreza: aplicação de uma abordagem multidimensional ao caso brasileiro", Textos para discussão, No. 223, Belo Horizonte, Regional Development and Planning Centre (CEDEPLAR).

Markunsen, A. (2006), "Urban development and the politics of a creative class: evidence from the study of artists", Environment and Planning A, vol. 38, No. 10, London, Pion.

Neri, M. (2008), "A perceived human development index", paper presented at the XVI National Meeting on Population Studies, Brazilian Association for Population Studies (ABEP).

Noronha, K.M.S. (2005), "A relação entre o Estado de saúde e a desigualdade de renda no Brasil", thesis, Belo Horizonte, Regional Development and Planning Centre (CEDEPLAR)/Federal University of Minas Gerais.

Ribas, R., A. Machado and A. Golgher (2011), "Flutuações e persistência na pobreza: uma análise de decomposição transitória-crônica para o Brasil", Pesquisa e Planejamento Econômico, vol. 41, No. 2, Rio de Janeiro, Institute of Applied Economic Research (IPEA).

Reither, E., R. Hauser and Y. Yang (2009), "Do birth cohorts matter? Age-period-cohort analyses of the obesity epidemic in the U.S.", Social Science and Medicine, vol. 69, No. 10, Amsterdam, Elsevier.

Rocha, S. (2003), Pobreza no Brasil: afinal, de que se trata?, Rio de Janeiro, Editora FGV.

Rocha, L., R. Moreira and G. Santos (2008), "Índice de desenvolvimento da familia (IDF): uma análise para as microrregiões e grupos demográficos do estado de Minas Gerais", Anais do XVIII Seminário sobre a Economia Mineira [Proceedings of the 18th Seminar about Economy in Minas Gerais], Belo Horizonte, Federal University of Minas Gerais.

Sen, A. (2001), Desigualdade reexaminada, São Paulo, Record. (1999), Development as Freedom, Oxford, Oxford University Press.

Silva, M. and R. Barros (2006), "Pobreza multidimensional no Brasil", Anais do XXXIV Encontro Nacional de Economia [Proceedings of the 34th Brazilian Economics Meeting], Rio de Janeiro, National Association of Postgraduate Centers in Economics.

Thorbecke, E. (2005), "Multi-dimensional poverty: conceptual and measurement issues, Brasilia", paper presented at the International Conference "The many dimensions of poverty", Brasilia, International Poverty Centre.

World Bank (2006), "Brazil: measuring poverty using household consumption", Report, No. 36358-BR, Washington, D.C.

Yang, Y. (2008a), "Trends in U.S. adult chronic disease mortality 1960-1999: age, period, and cohort variations", Demography, vol. 45 , No. 2 , Springer.

(2008b), "Social inequalities in happiness in the U.S. 19722004: an age-period-cohort analysis", American Sociological Review, No. 73, Sage.

(2007), "Is old age depressing? Growth trajectories and cohort variations in late- life depression", Journal of Health and Social Behavior, vol. 48, No. 1, Sage.

Yang, Y. and L. Lee (2009), "Sex and race disparities in health: cohort variations in life course patterns", Social Forces, vol. 87, No. 4, Oxford, Oxford University Press. 